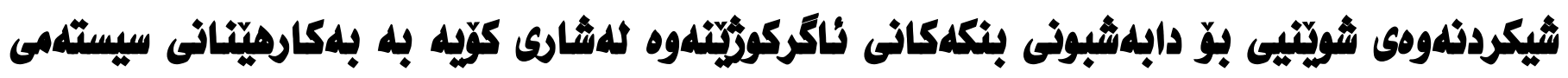 زانيارييه جوكرافييلكان
}

\section{روّستهم سلام عزيز}

بهاشى جوكرافيا، فهكهلتى بهروهرده، زانكوى كويه، كويه، هلريّمى كوردستان، عيّراق. بيمهيل: بstam.salam@koyauniversity.org

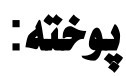

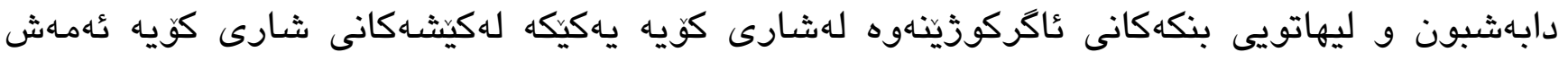

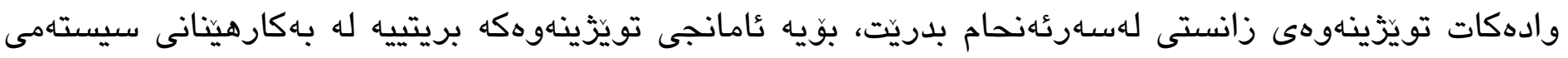

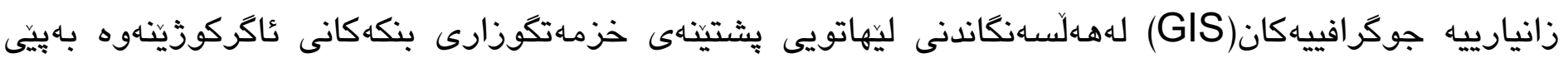

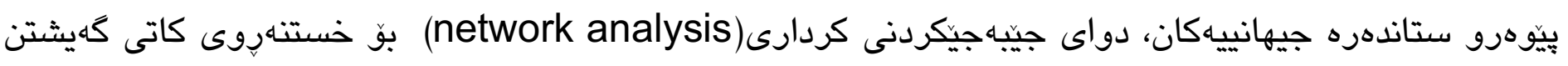

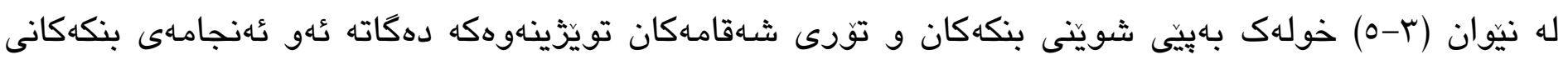

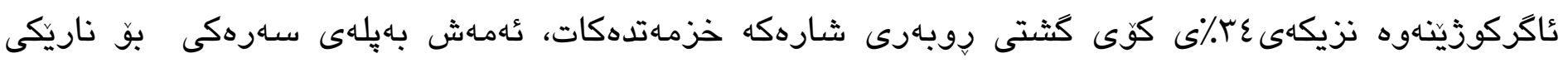

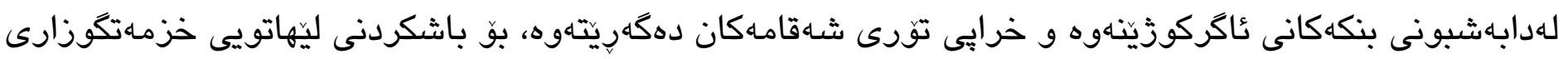

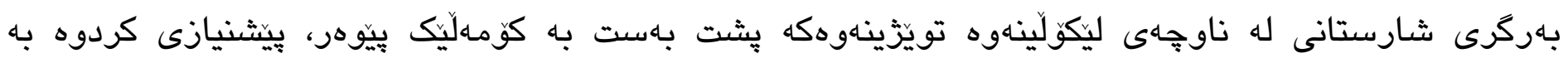

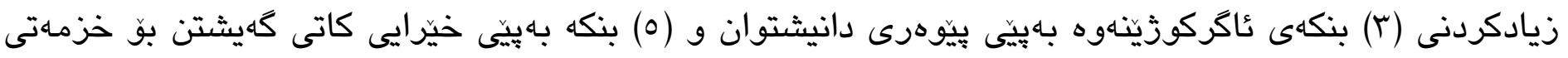

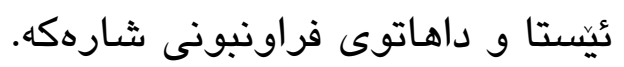

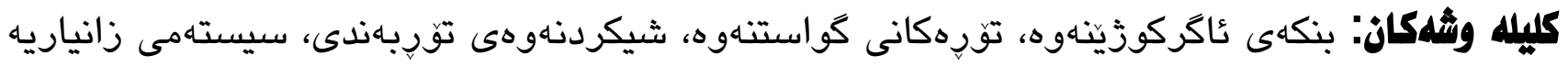

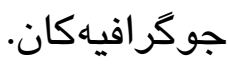


يشت بهاستن به تهكيكى سيستهمى زانيارييه جوكرافييهكان(GIS) بوّ هـلّسهنكاندنى ليَهاتويى دابهشبونى خزمهتكوزارييهكان بوّته يِيّويستييهكى سهرهكى ئهنجامدانى تويَّزينهوهى زانستى لهم بوارهدا، خزمهتكوزارى بهركرى شارستانى بهتايبهتيش خزماهتكوزارى عاكركوزاندنهوه زياد له خزماتكوزارييهكانى تر دهتواني سودمهاندبى

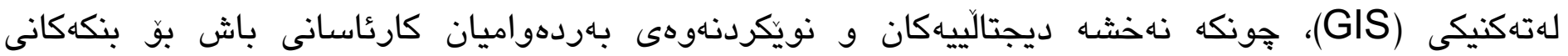

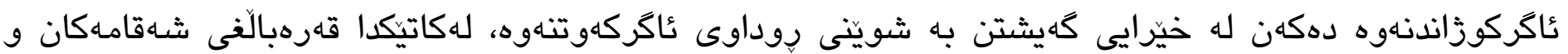

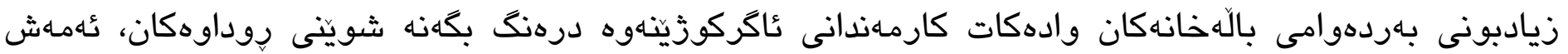

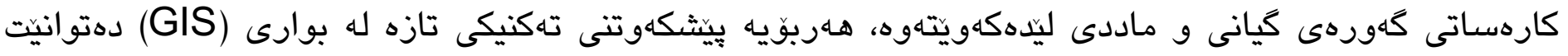

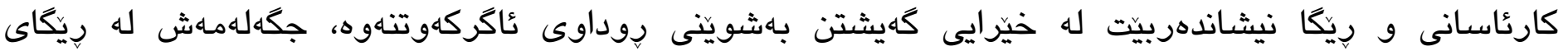

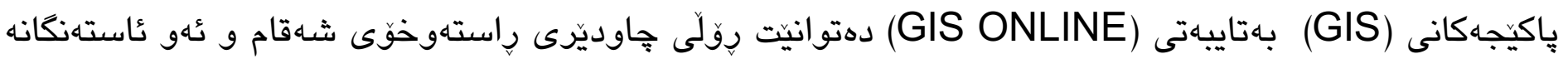

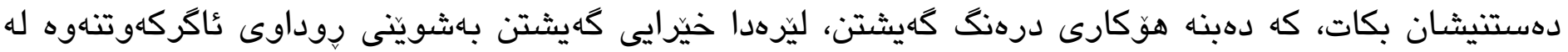
كرنكترين ئهركى خزمهاتكوزارى بهركرى شارشتانى دهبيت، واته ليَهاتويى ئه خزمهتكوزارييه بهانده بهكاتى كهيشتن (GIS for the Fire Service, An Esri® White Paper, June 2012,, n.d.) (ولآته يهككرتوهكانى ئهماريكا و كهنها و بئوستراليا و بهريتانيا) كاتى كهيشتنى نمونهيى بو شوينى عاكركهوتناهوه

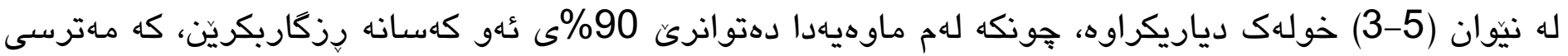

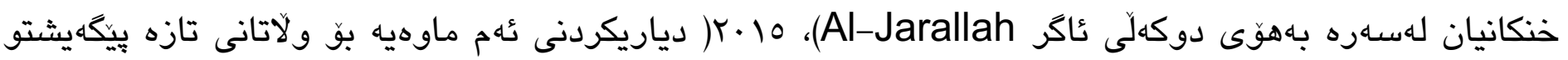

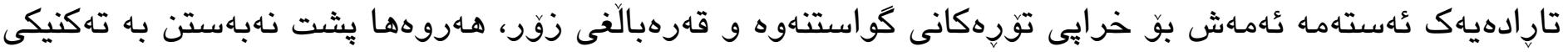

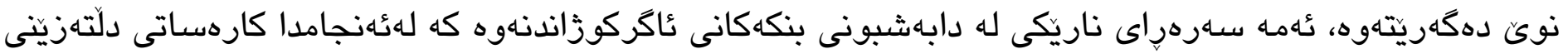

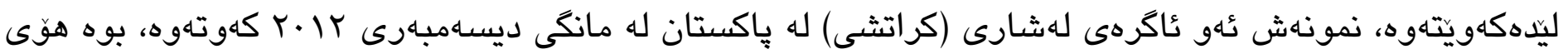

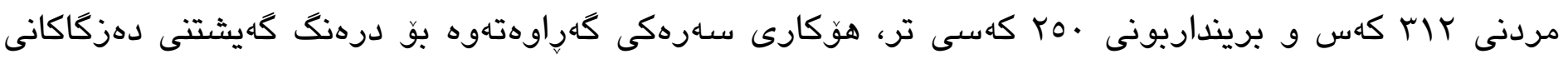

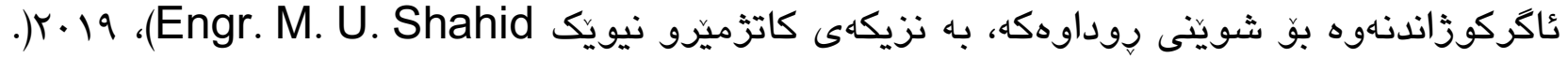

جهاندين تويّزينهوهى زانستى لهم بوارهدا ئهنجامدراوه كه جهختيان له سود وهركرتن له تهكنيكى سيستهى زانيارييه جوكرافييهكان(GIS) لهبوارى ئيدارهدان و كارئاسانى خزمهتكوزارى بهركرى شارستانى بينيوه، لهوانه تويَزينهوهى لئي

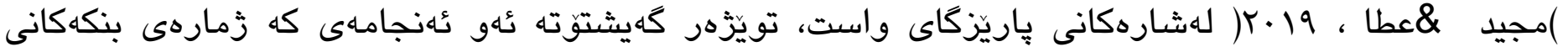

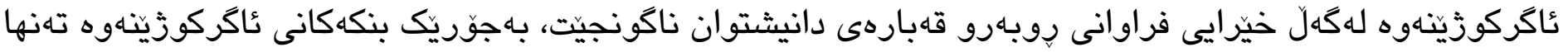

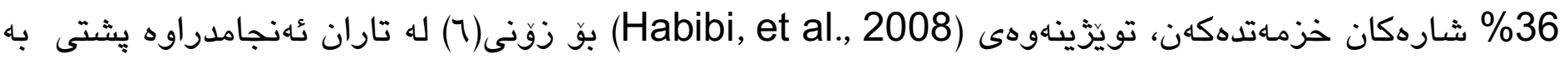

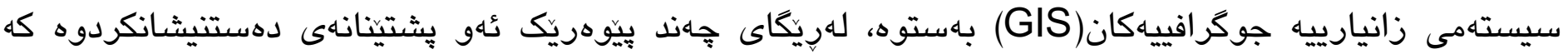




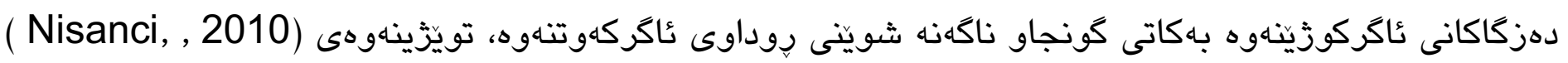
لهسـار شـارى (Trabzon) لهتوركيا ئهنجامدراوه تويّزهر لهريخاى (GIS) داتابهيسيكى تهواوى داناوه بوّ زمارهى

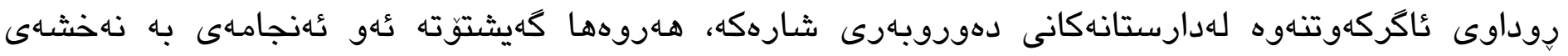

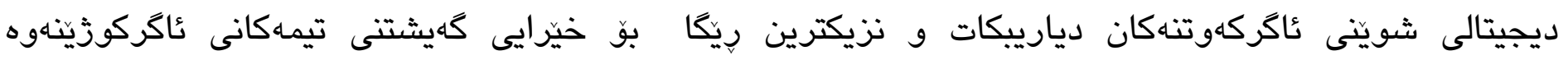

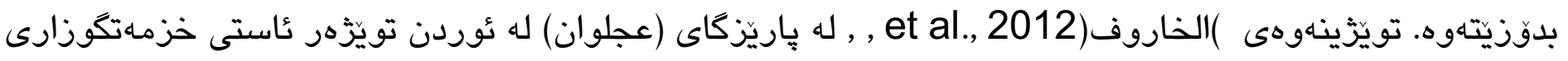

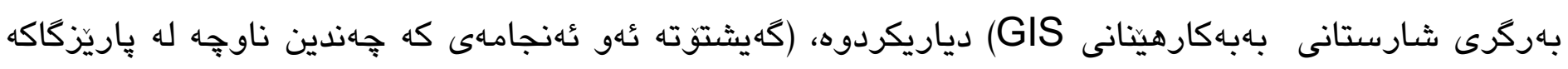

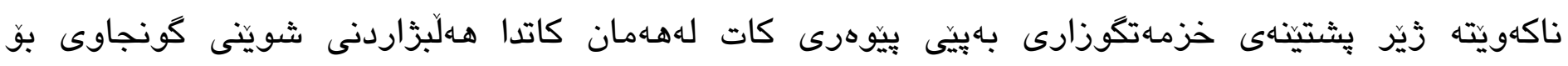

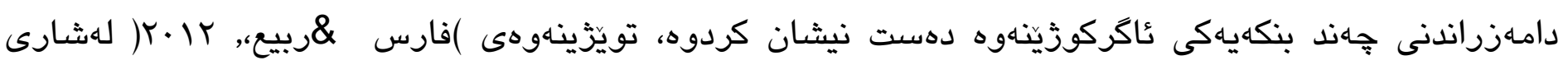

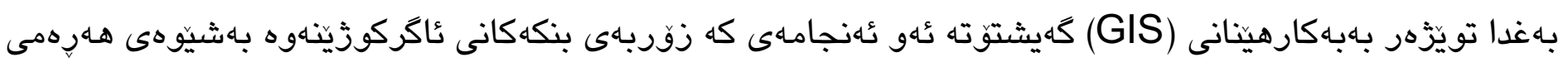

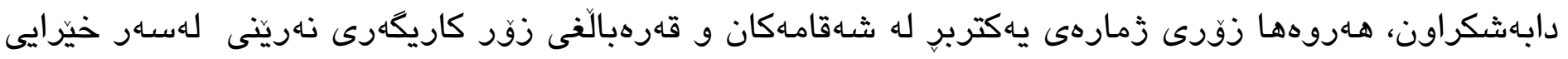

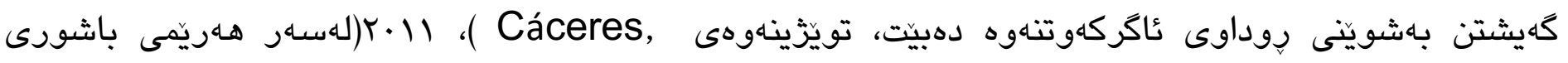

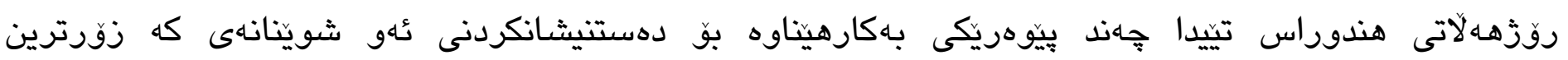

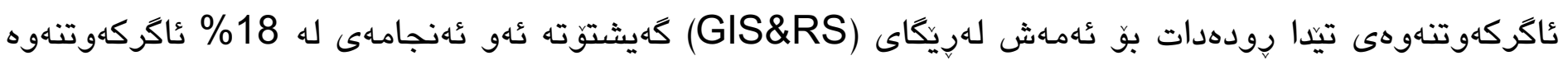
لهئاستى زقر مـترسيداره و 32\% له ثٔاستى مام ناوهند و V\%ع له ثاستى نزمدايه.

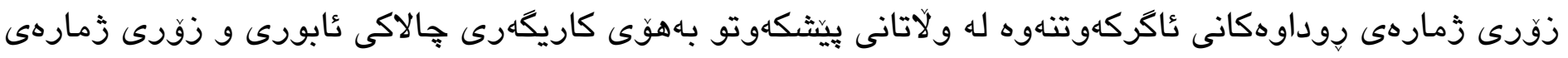

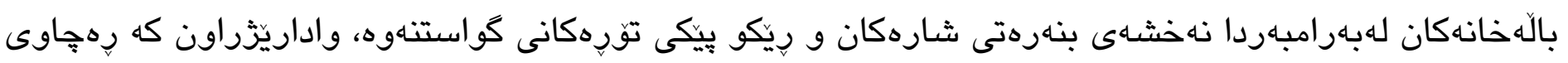
عاسـانكارى كراوه له خيّرايى كهيشتن بهروداوهكان هـهريويه كهمترين زيانى كيانى ومادديان بهبهراورد بهشارهكانى

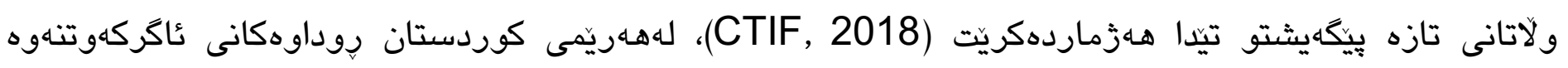

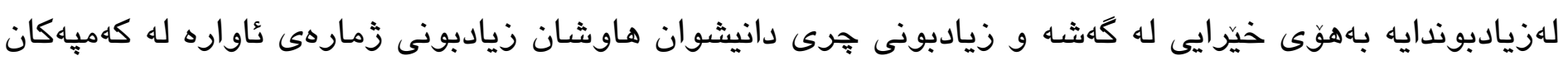

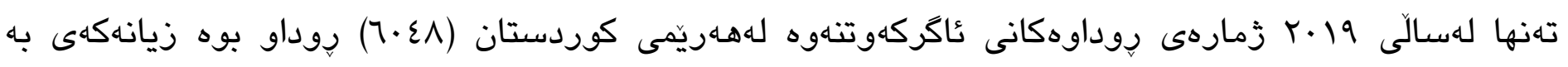

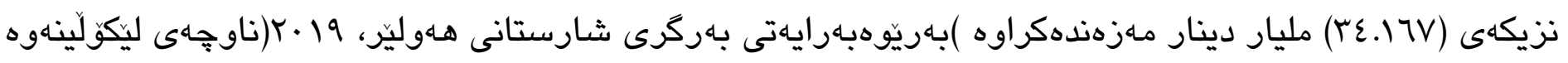

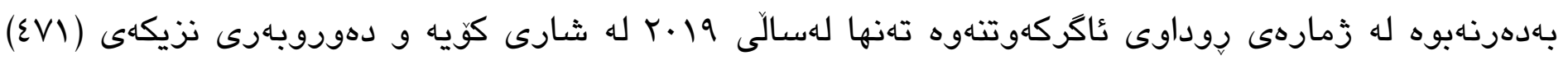

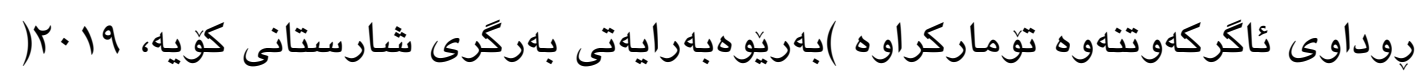




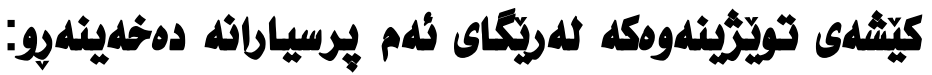

ا. تاجهاند زمارهى بنكهكان و دابهشبونيان لهكهل بيّوهره جيهانييهكان كونجاوه؟

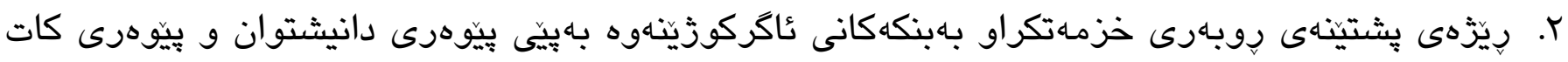

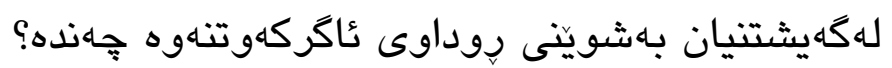

ئامانجى تويَزينهوهكه بريتيدهبيت له شيكردنهوى بارى ئيستاى دابهشبونى بنكهكانى عاكركوزيَّهوه لـ شارى

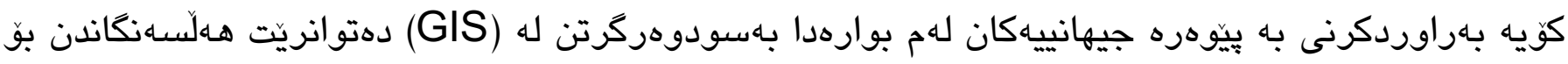

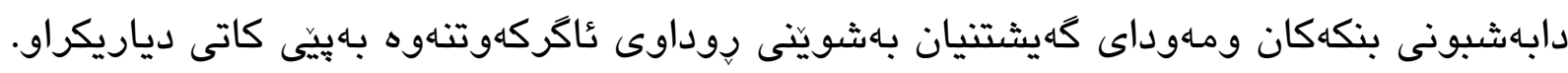

كريمانى تويّزينهوهكه بريتيهله:

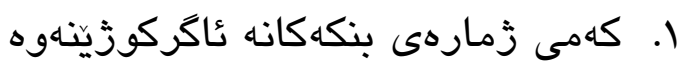

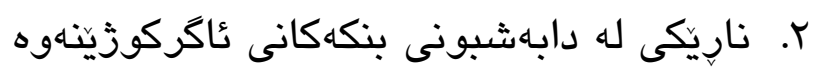

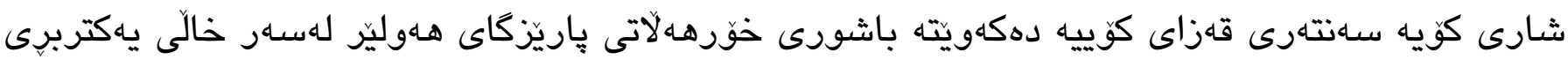

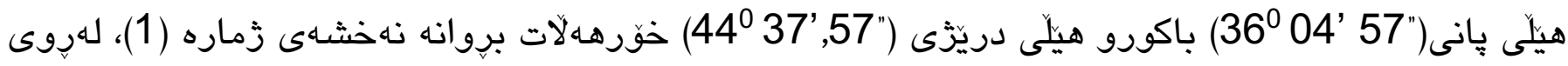

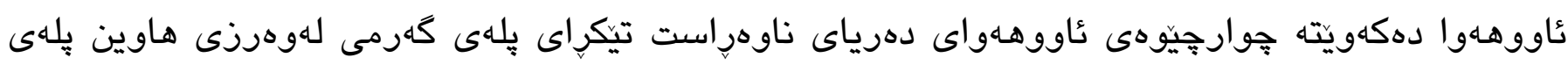

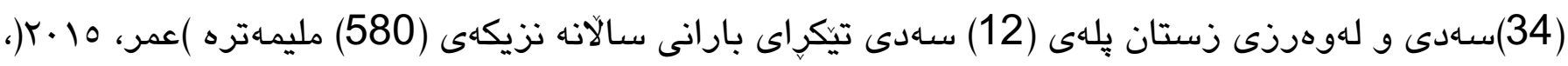

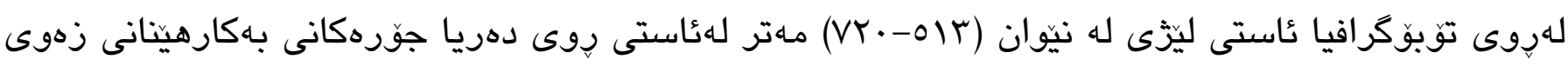

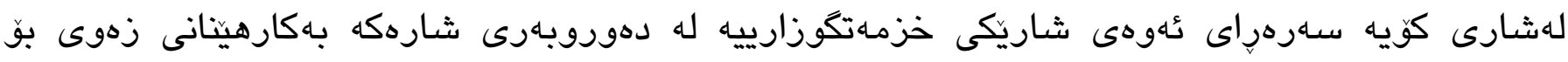

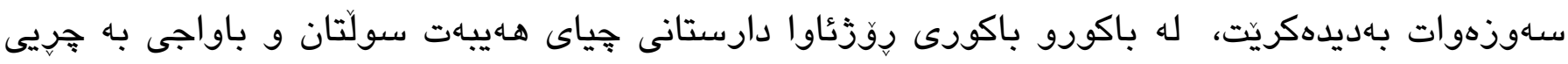

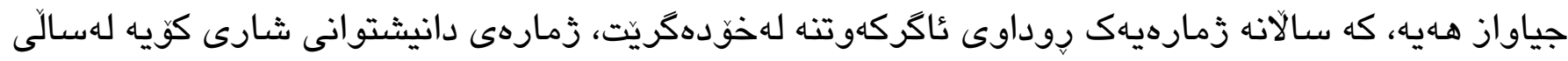

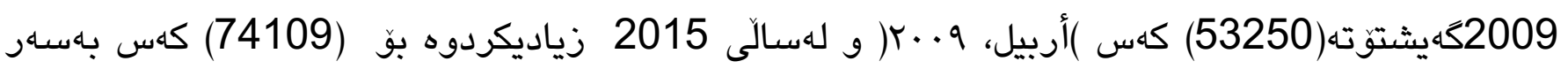

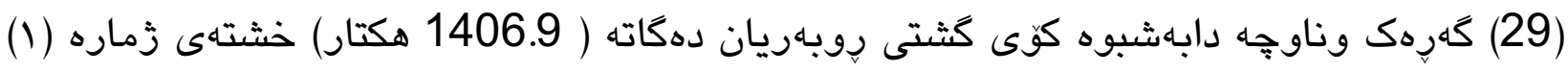




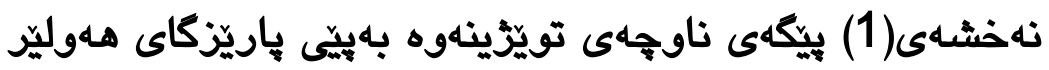
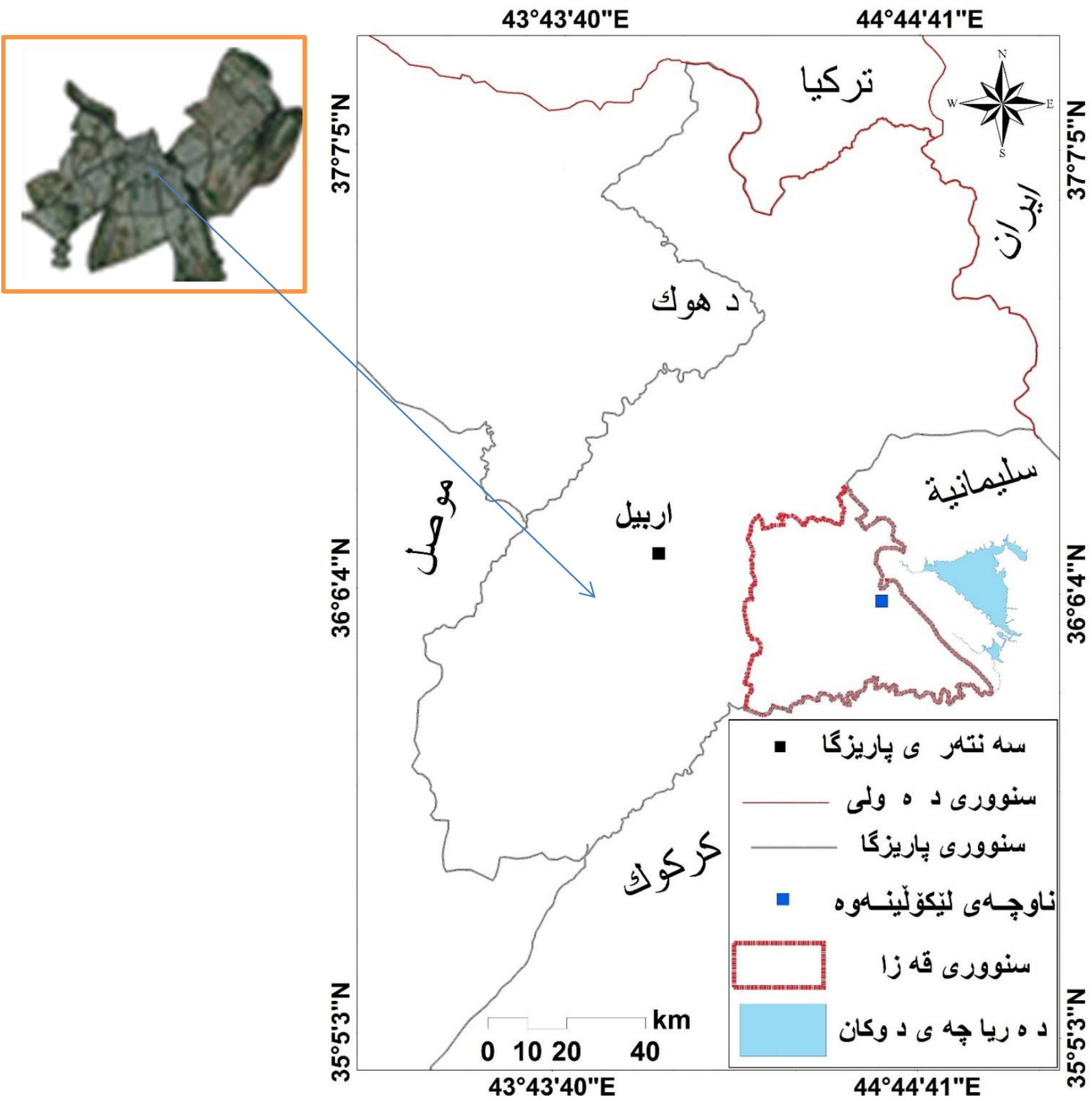

(Haddad \& Mahmood, 2016) 
خشتهى (1) زمارهى دانيشتوان و رويهرى كهرهكهانى شارى كويه له سالى 10 r r

\begin{tabular}{|c|c|c|c|}
\hline يوبلهرى كهروكى /هكتار & ثرمارمى دانيشتوان & ناوى كلهرِك & 3 \\
\hline 14.7 & 2336 & دلّدار & 1 \\
\hline 61.4 & 4790 & مهابات & $r$ \\
\hline 32.8 & 133 & كيله خوار & $r$ \\
\hline 24.7 & 40 & كؤسرهت & $\varepsilon$ \\
\hline 25.8 & $r 199$ & حهماموك & 0 \\
\hline 25.8 & 1433 & بايزاغا & 7 \\
\hline 19.1 & 3127 & ق قلات & $v$ \\
\hline 52.5 & 8118 & ئازادى & $\wedge$ \\
\hline 136.9 & 5423 & زانكو & 9 \\
\hline 99.3 & 538 & كهميى زانكو & 1. \\
\hline 33.3 & 1662 & بهفرى قهندى & 11 \\
\hline 95.0 & 8473 & فيدرِالى & ir \\
\hline 37.7 & MITE & حاجى قادر & ir \\
\hline 77.8 & rrot & هامون & $1 \varepsilon$ \\
\hline 98.2 & 376 & كهشتيارى & 10 \\
\hline 30.3 & 3100 & سهرباغ & 17 \\
\hline 28.1 & 6581 & سهربهستى & iv \\
\hline 152.7 & 1484 & قهنديل & 11 \\
\hline 71.5 & $0 . v \varepsilon$ & زانست & 19 \\
\hline 35.6 & - & 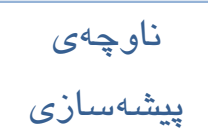 & $r$. \\
\hline 14.2 & 687 & هـهارموّته & H \\
\hline 42.3 & 454 & جوارجرا & rr \\
\hline 37.8 & 5722 & كهكون & rr \\
\hline 64.7 & 3985 & رإِرين & $r \varepsilon$ \\
\hline 25.2 & $r$ r. & ئاسقو & ro \\
\hline 23.0 & 818 & عُاسوّس & r \\
\hline 17.1 & $\wedge \varepsilon 0$ & ن لى & rV \\
\hline
\end{tabular}




\begin{tabular}{|c|c|c|c|}
\hline 11.1 & 797 & قسرىن & rA \\
\hline 18.2 & $r \cdot o$ & رزكارى & rq \\
\hline 1406.9 & $V \varepsilon 1 \cdot 9$ & كقّى كُشتى & \\
\hline
\end{tabular}

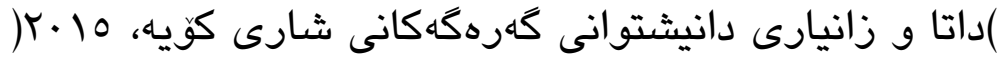

سهارهتاى دروستبونى فهرمانكهى بهركرى شارستانى له ناوجهى تويَّزينهو بوّ سالّى 1978 دهكهرِيتهوه، لهئيستادا بنكهانى عاكركوزيَّاهوه له (3) بنكه يِكهاتون، كه بريتين له: (كويه، هـرموّته، زانكو) خشتهى زماره (2) هـريهكهيان وا دبهشكراون ئهركى خزمهتكردنى جههندين كهرهك لهخوّكرن.

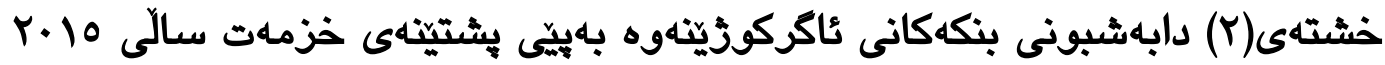

\begin{tabular}{|c|c|c|c|c|c|}
\hline يشتينهى خزمهلكردن & كائلمفهرو & 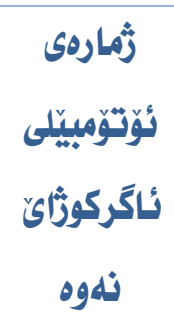 & شئكهى & 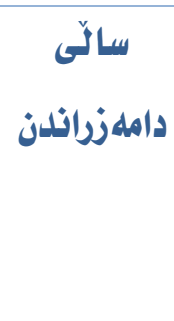 & بنكه \\
\hline 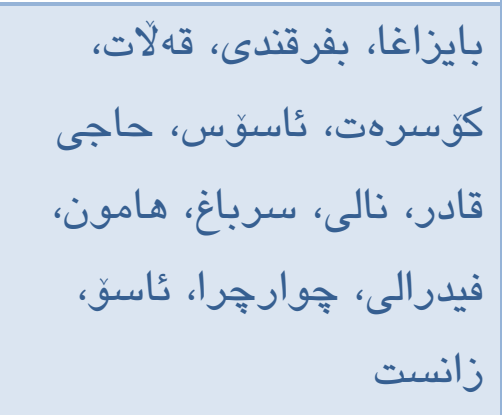 & 36 & 2 & كايز كاغاه & $19 \mathrm{VA}$ & كويه \\
\hline 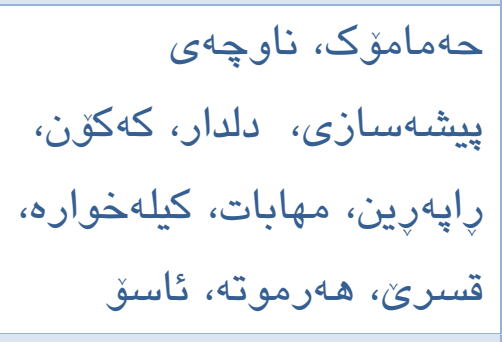 & 36 & 1 & سِّه & r.l. & ته هـرمو \\
\hline 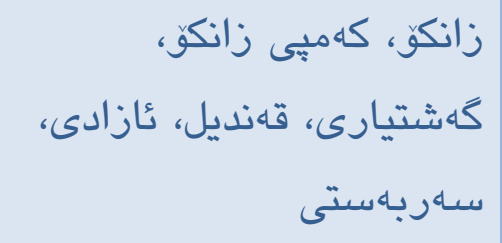 & 36 & 1 & كزهيك & $r \cdots \varepsilon$ & زانكو \\
\hline
\end{tabular}

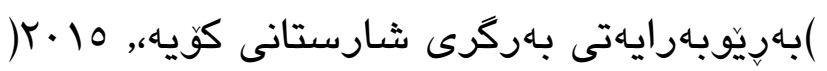




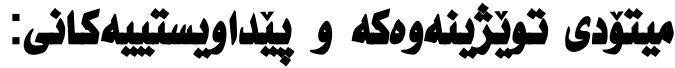

باهماهبهتى كَهيشتن به ئهنجامى وردى تويَزْينهوهكه دو قوّناغى كرنكى بيّويسته:

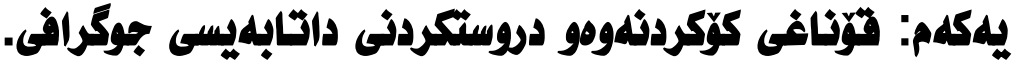

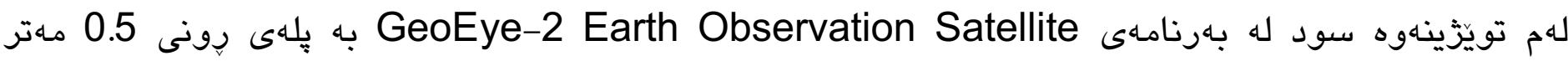
Spatial Resolution

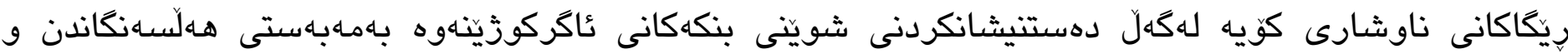
شيكردنهوهى شوينيى بهييّى ثٔهو داتابهيسهى كه دروستكراوه بشت به بهرنامهى ArcGIS10.5 بهستراوه، لهيكيكاى

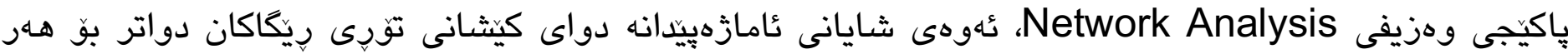

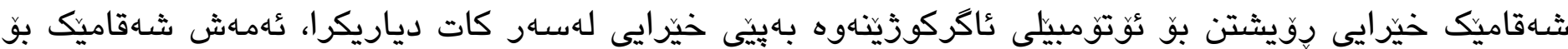

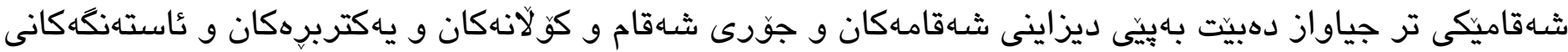

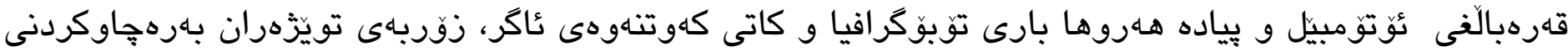

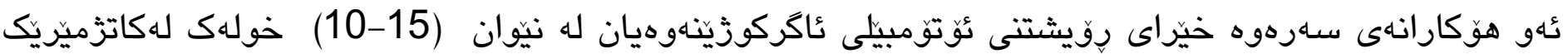
دياريكردوه.

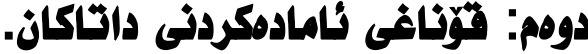

لهم قوناغهدا تويَّهر دهستى كردوه بهدروستكردنى بنهماى داتاو زانيارى جوكرافى لهرِيَّاى

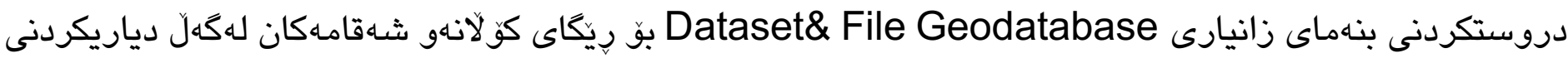

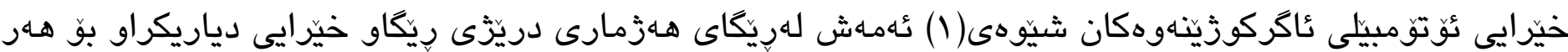

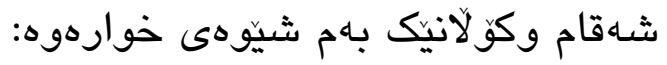

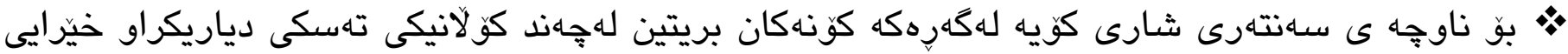
لهنيّوان (20-15)كم لهكاتزّميّريكدا دانراوه.

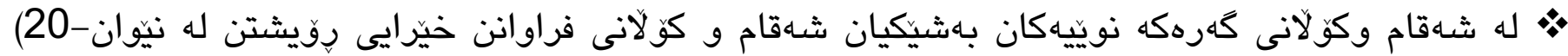
(40 كم له كاتزميرّيكد دانراوه. 
شيّوهى(() هيلكارى ميتودى تويزّينهوهك

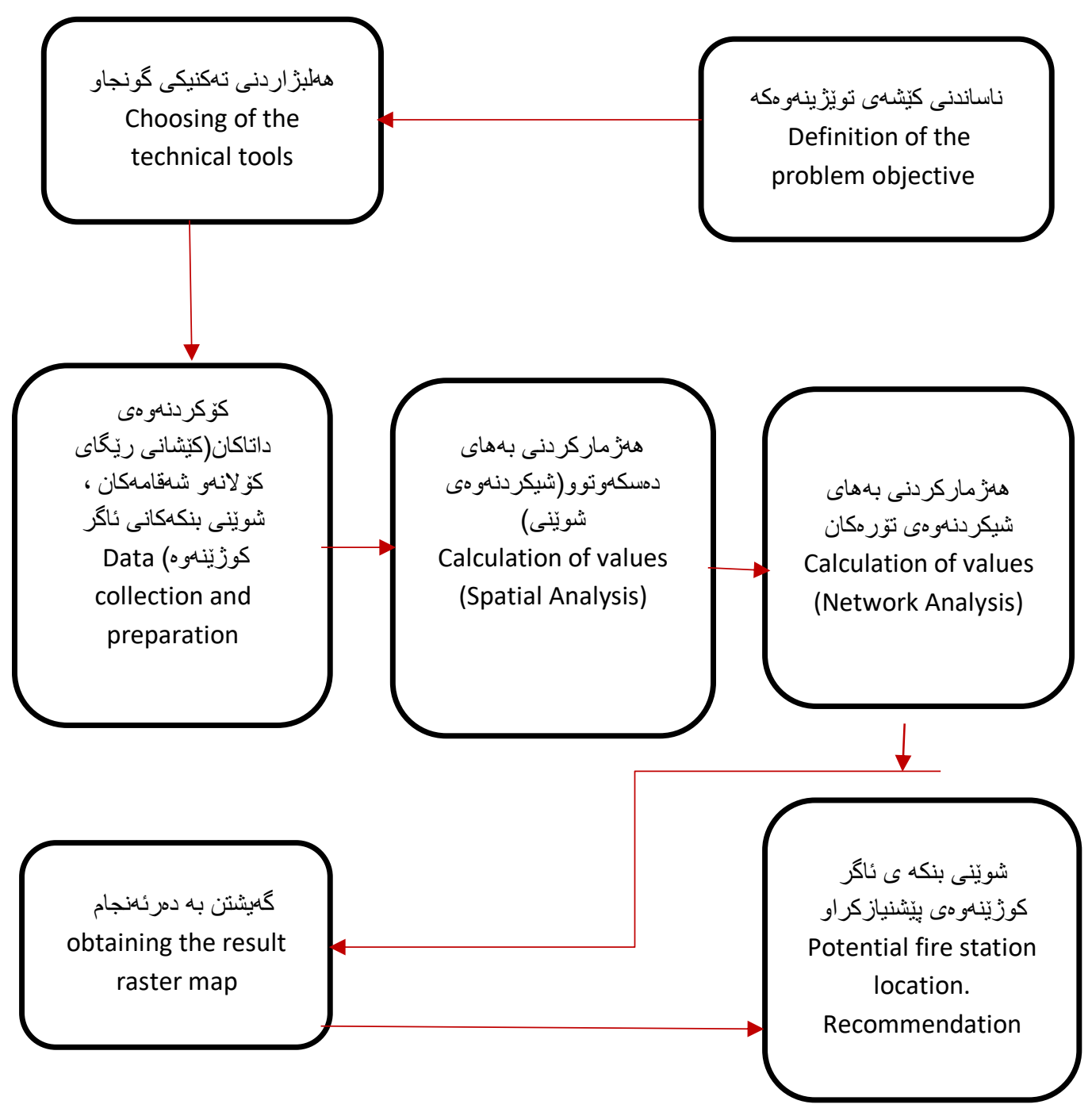

بهوَى ئهوهى ستاندهرى جيهانى خيّرايى كَهيشنى بو شوينى ناكركهوتناهوه دياريكردوه له نيّوان كاتى وهلامدانهوه Response Time تاكو كَهيشتنى شوينى روداوهكه Reflux Time بهماوهى دئى دياريكراو

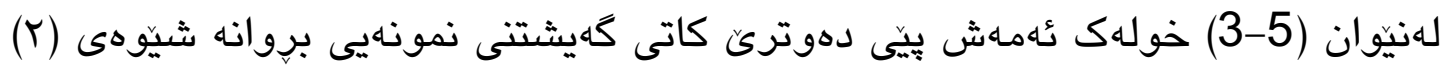


شيّيوه(Y) كاتهكانى كهيشتنى خيّرايى نمونهيى بو شوينى ثُكركهوتنهوه

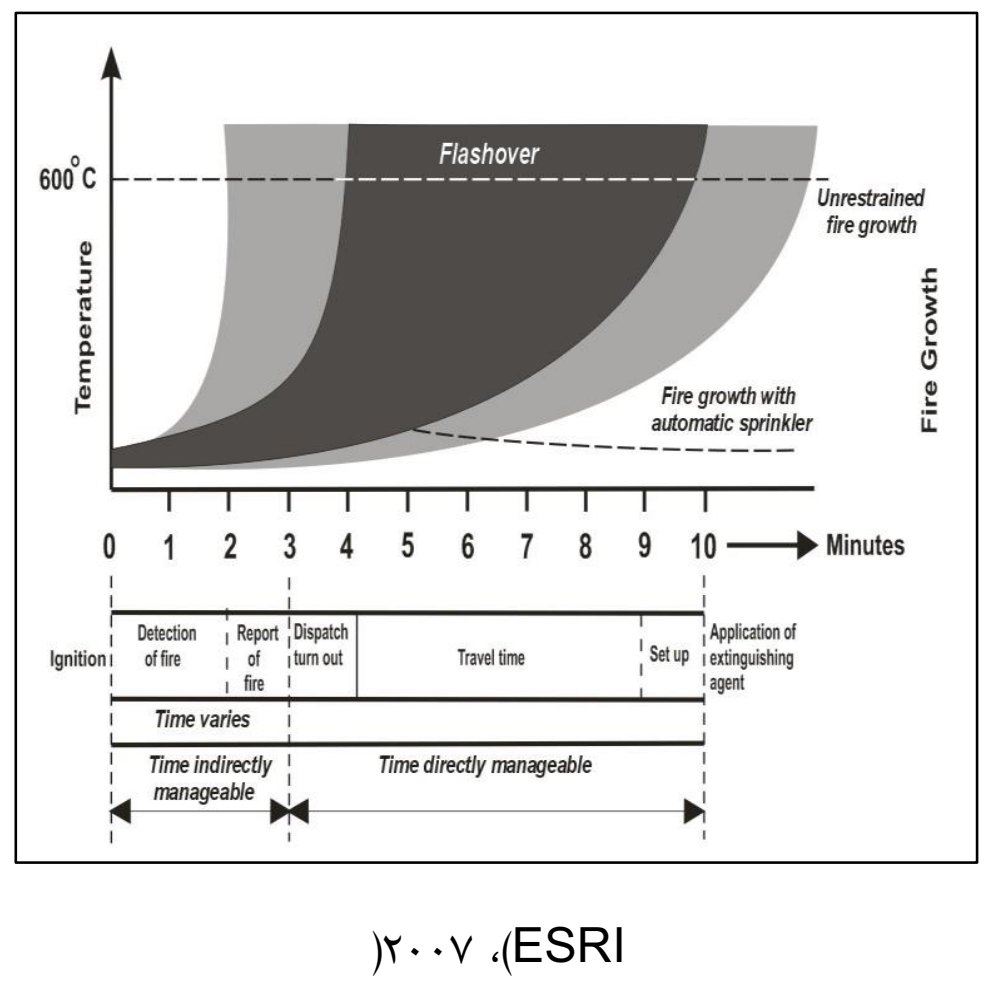

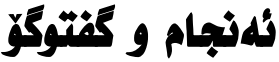

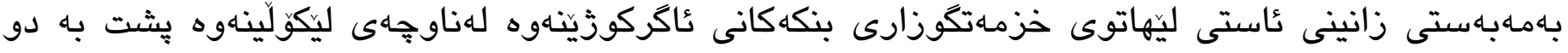
بيّيوهر دهبهاستىن:

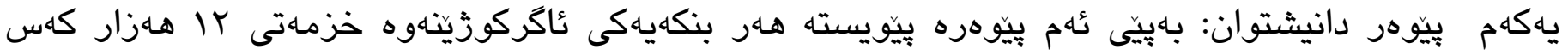
دانيشتوان بكات )وزارة الاعمار والاسكان-، •(r( بهتيبينيكردن له خشتهى(r) دهردهكيى كه زمارهى

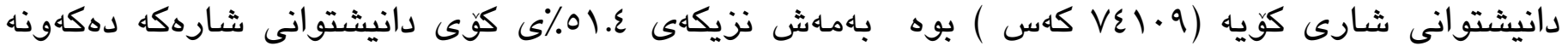

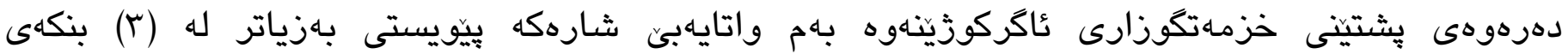
عاكركوزيَناهوه دهبئ. 
خشتهى (3) ييّويستى ناوجهى ليكولينهوه به كردنهوهى بنكهى ئاكركوزينهوه لهسهر بنهماى بيّوهرى قهبارهى

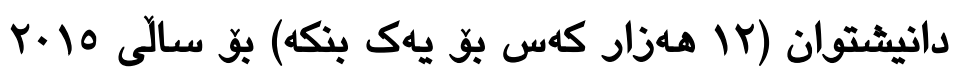

\begin{tabular}{|c|c|c|c|c|c|}
\hline 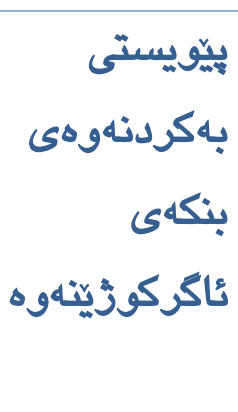 & \% زانيشتى زانى & زيادهى & 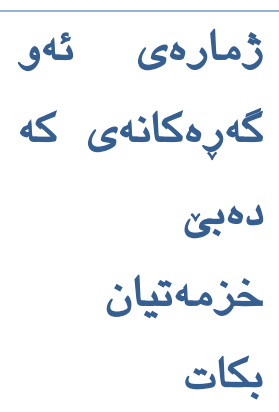 & رانيشارهى & ناوى \\
\hline 1 & 71.1 & $\mid M \Lambda I I$ & 13 & $r \cdot \wedge l I$ & كويه \\
\hline 1 & $\varepsilon Y . r$ & AVVA & 10 & $r \cdot V \vee \Lambda$ & هـرموّته \\
\hline 1 & $\varepsilon 7 . V$ & $1.0 Y$. & 6 & TYOY. & زانكو \\
\hline r & $01 . \varepsilon$ & rNl.q & 29 & $V \varepsilon 1.9$ & كوىى كثنى \\
\hline
\end{tabular}

سهارجاوه: نامادهكراوه يشت بهايت به خشتهى (1) و(Y)

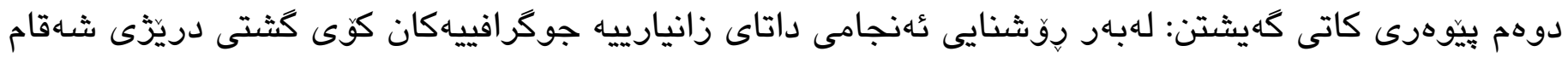

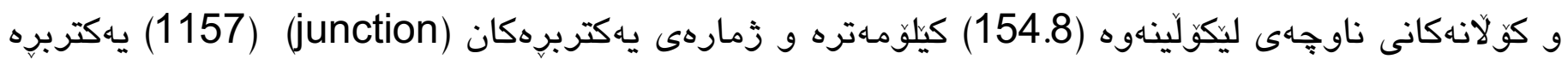

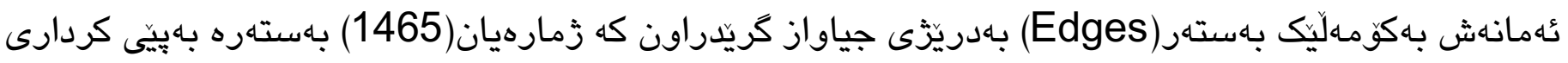

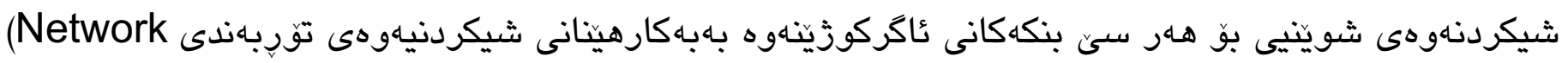

(2) نهخشه Analysis) 


\section{نهخشهى(2) تورى ريكاويان لهشارى كويه سالى 2018}

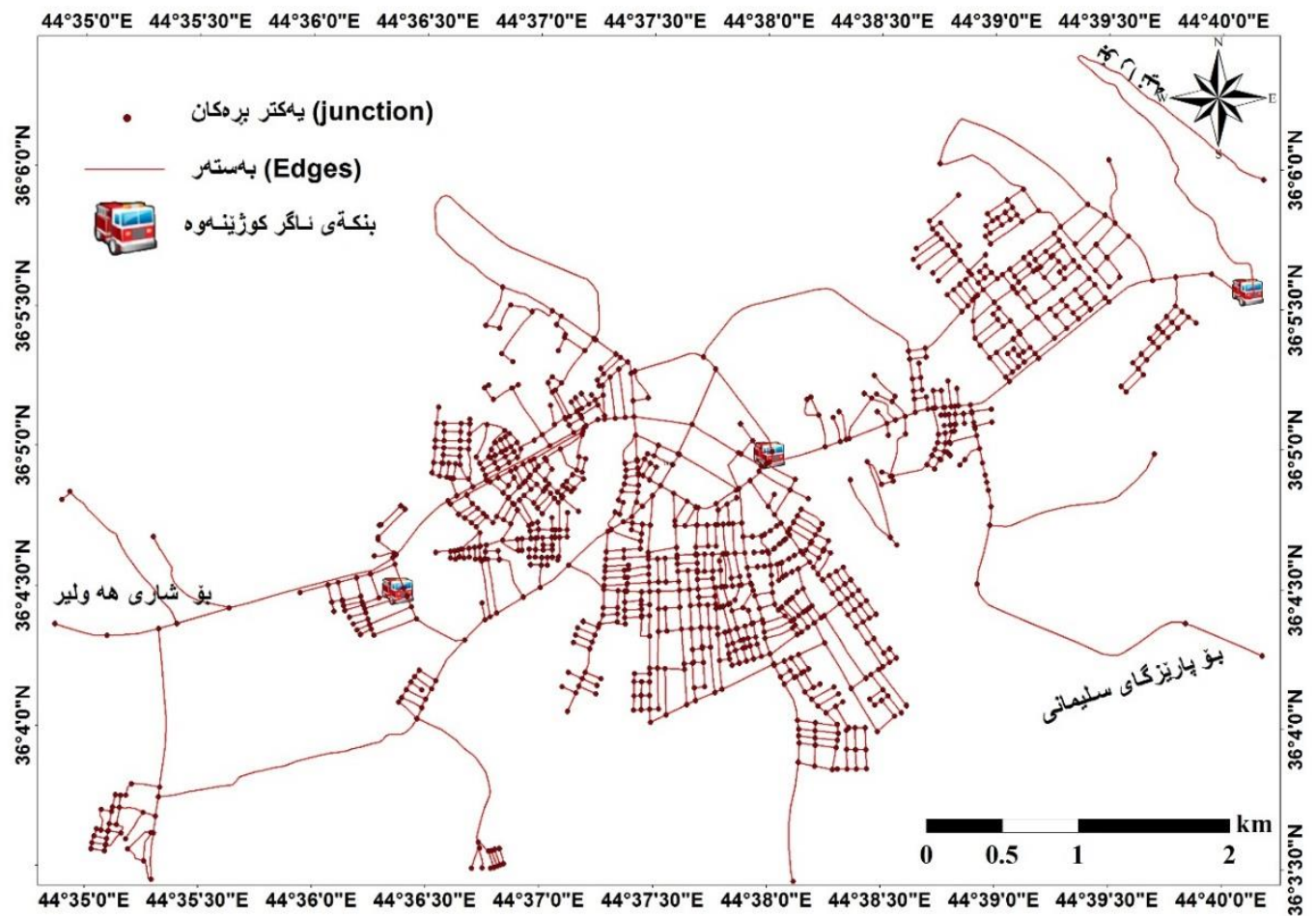

سهرجاوه: كارى تويَّزهر يشت بهاست به ويَنهى ئاسمانى GeoEye-2 Earth Observation Satellite به

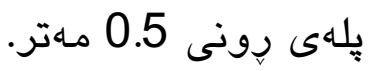

بو دياريكردنى ناوجهاءى خزمهتكراو بهايِيى كاتى كهيشتنى (5-3) خولهك لهاهر ئاستى شارهكها دهردهكهويت

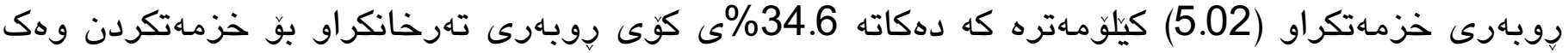
لهنهشهى (3) و خشتهى(3)دا دهردهكويّت له سهار ئاستى بنكهان بنكهى ئاكركوزيَّاهوهى كويه بهرزترين

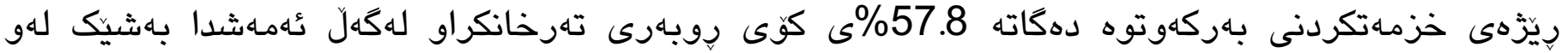
يشتينهى بوّى تهرخانكراوه بريتين له كَرهكه كؤنهانى شارهكه (بايزاغا، بفر قندى، قهلات) بهاهوَى تهسكى

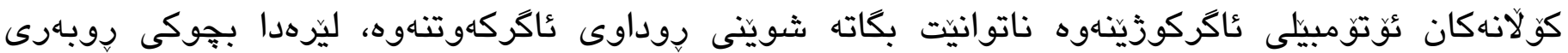

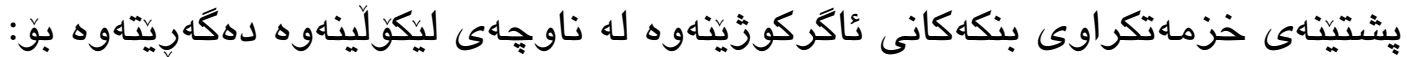

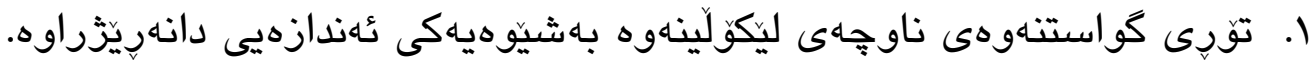

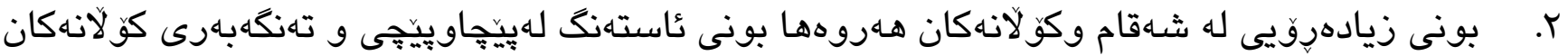

$$
\text { و بونى للهيهرى مروّيى(تاسـه). }
$$




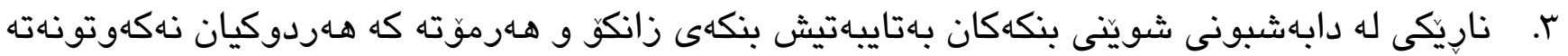

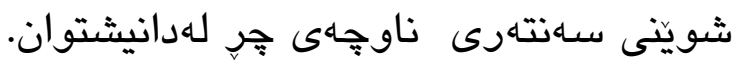

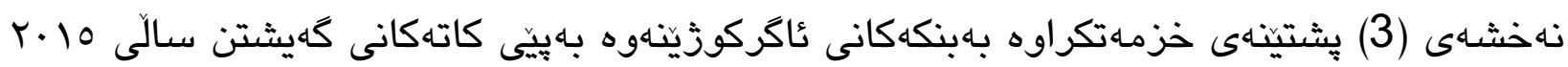

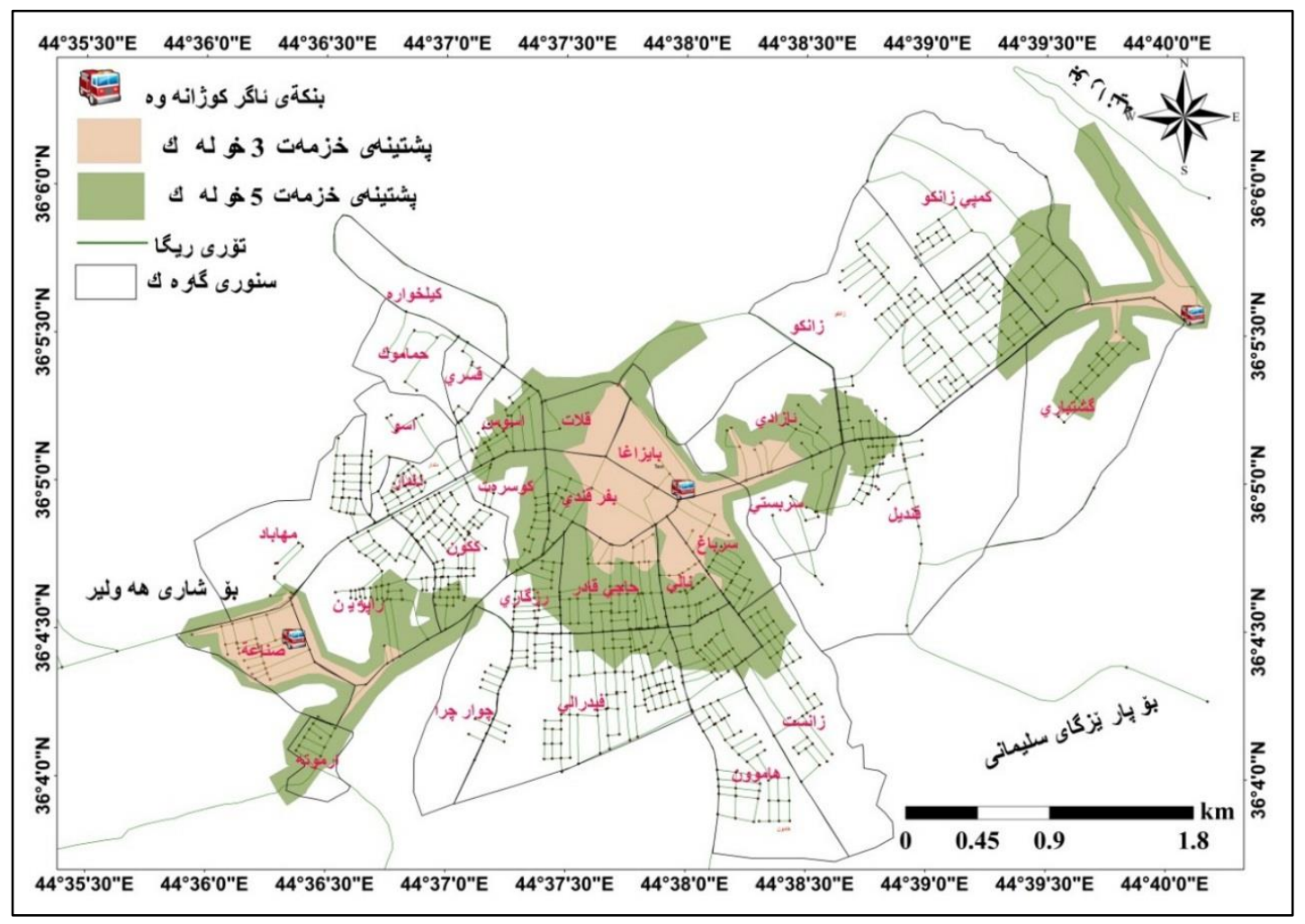

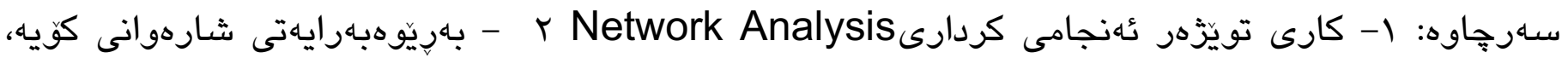

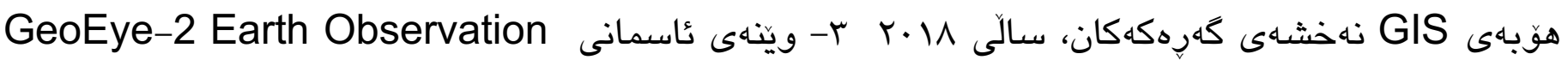
Satellite 


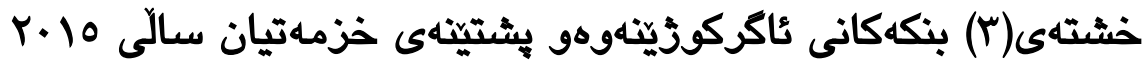

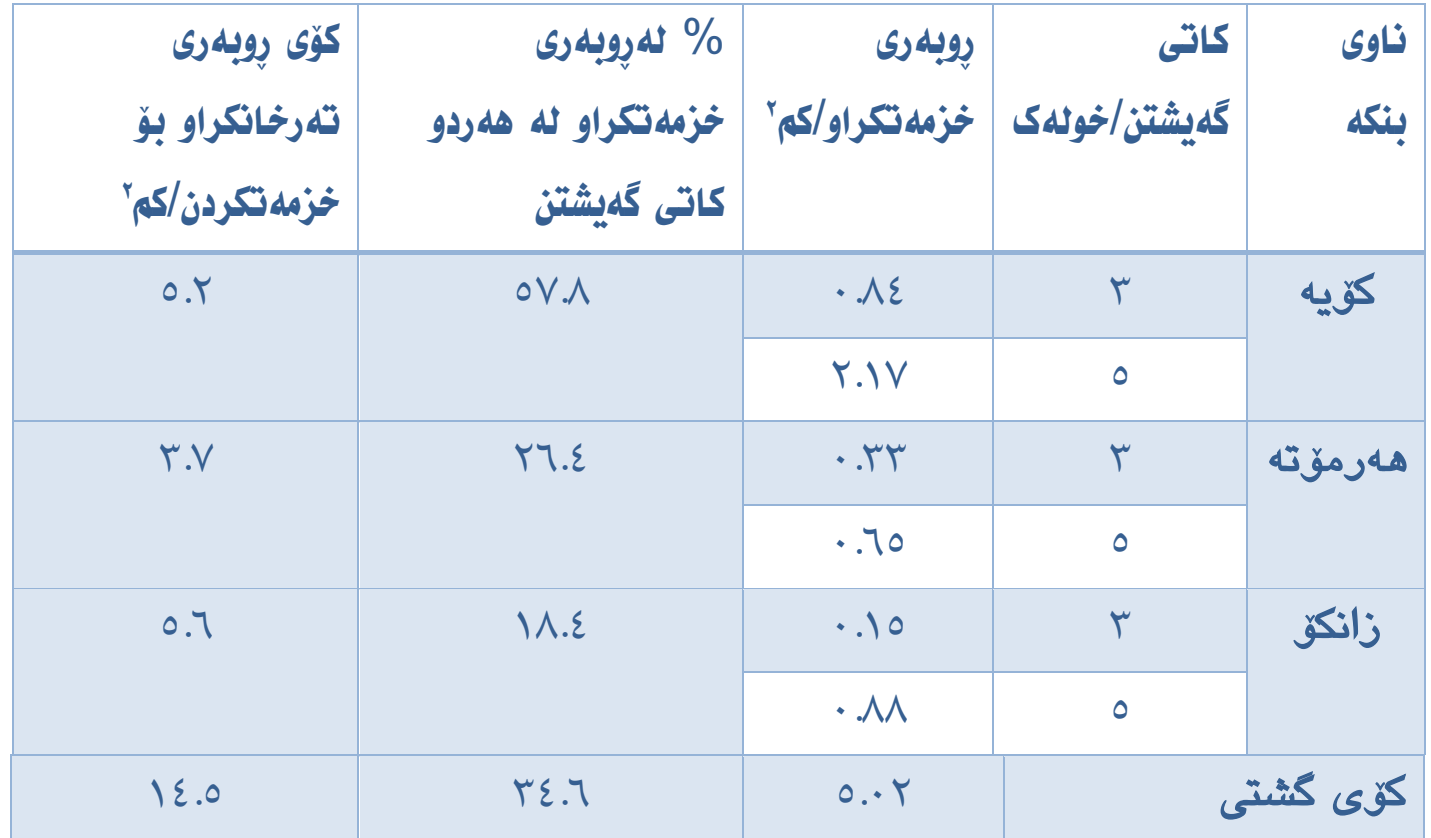

كارى تويَزْر به سودوهركرتن له نهخشاهى (ب)

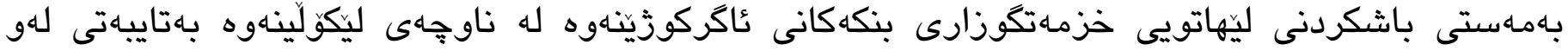

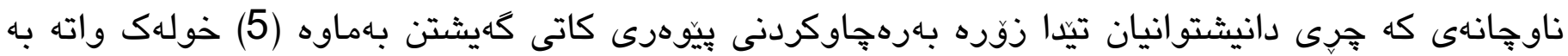

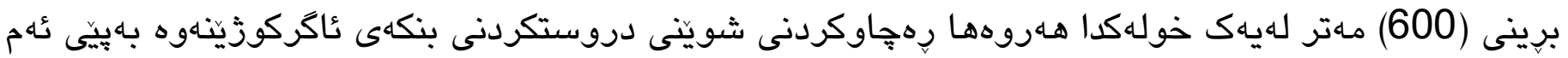

$$
\text { يُيّوهره سـرهكيانه: }
$$

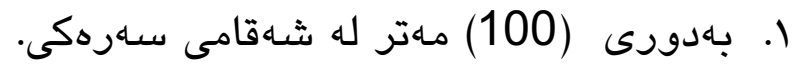

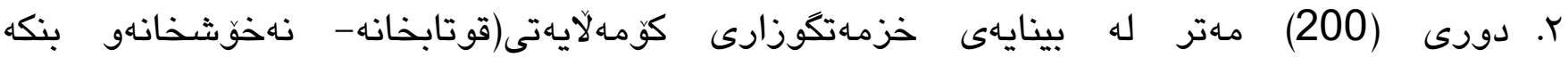

$$
\text { تهندروستييهكان). }
$$

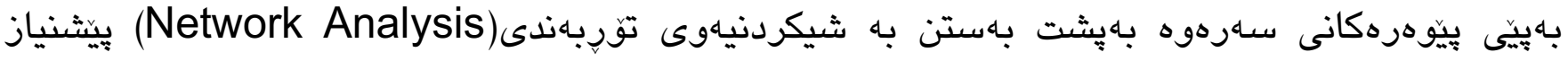

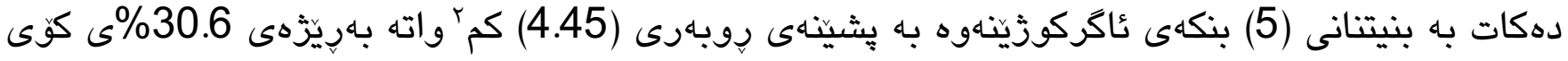

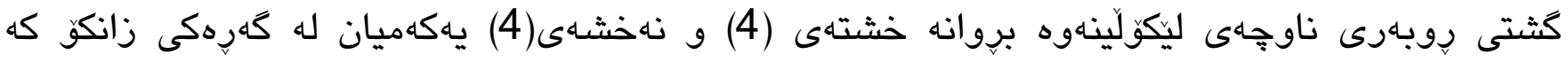
دهتوانيت خزمهتى تهواوى كَهرهكهانى (كهمبى زانكق، ئازادى، قهنديل، ساربهاستى ) بكات، دوهم وسيّياهميان

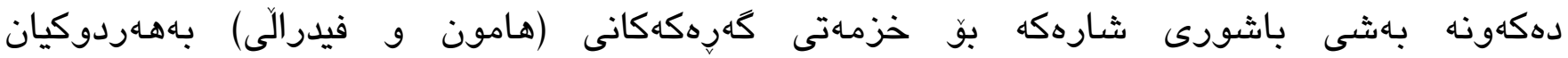

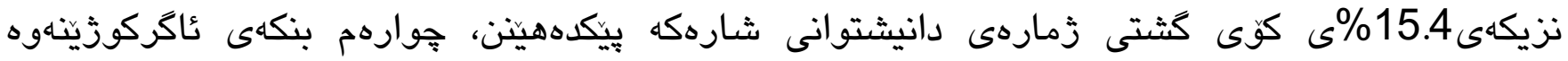

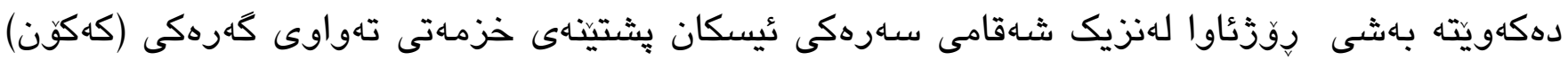

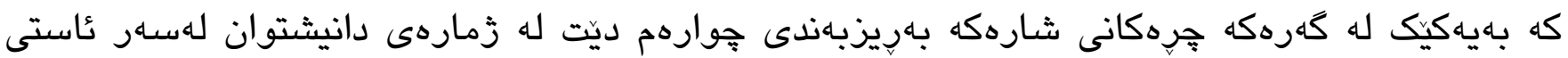




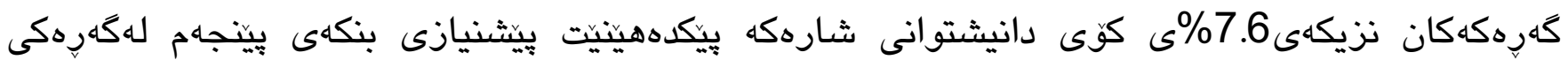

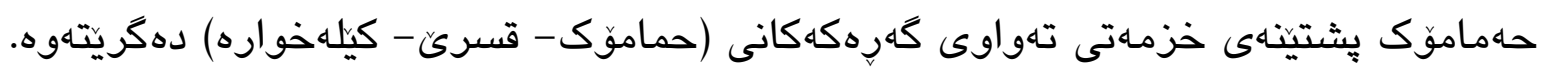

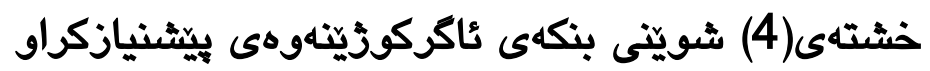

\begin{tabular}{|c|c|}
\hline بشتينهى يِوبهرى خزمهت كم & شوينى بنكهى يَيشنيازكراو بهييّى \\
\hline 1.02 & زانكو \\
\hline 1.12 & 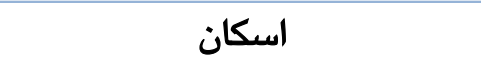 \\
\hline 1.05 & 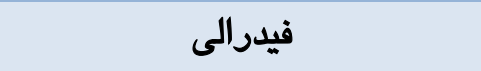 \\
\hline 0.64 & حماموك \\
\hline 0.63 & 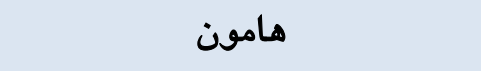 \\
\hline 4.45 & كوى كثتى \\
\hline
\end{tabular}

كارى تويَّهر بهسود وهركرتن له نهخشهى (3)

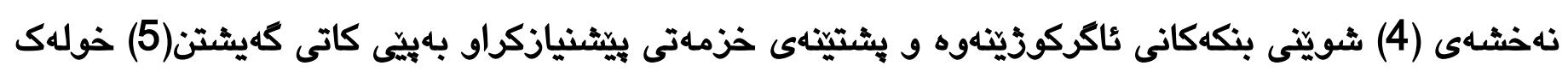

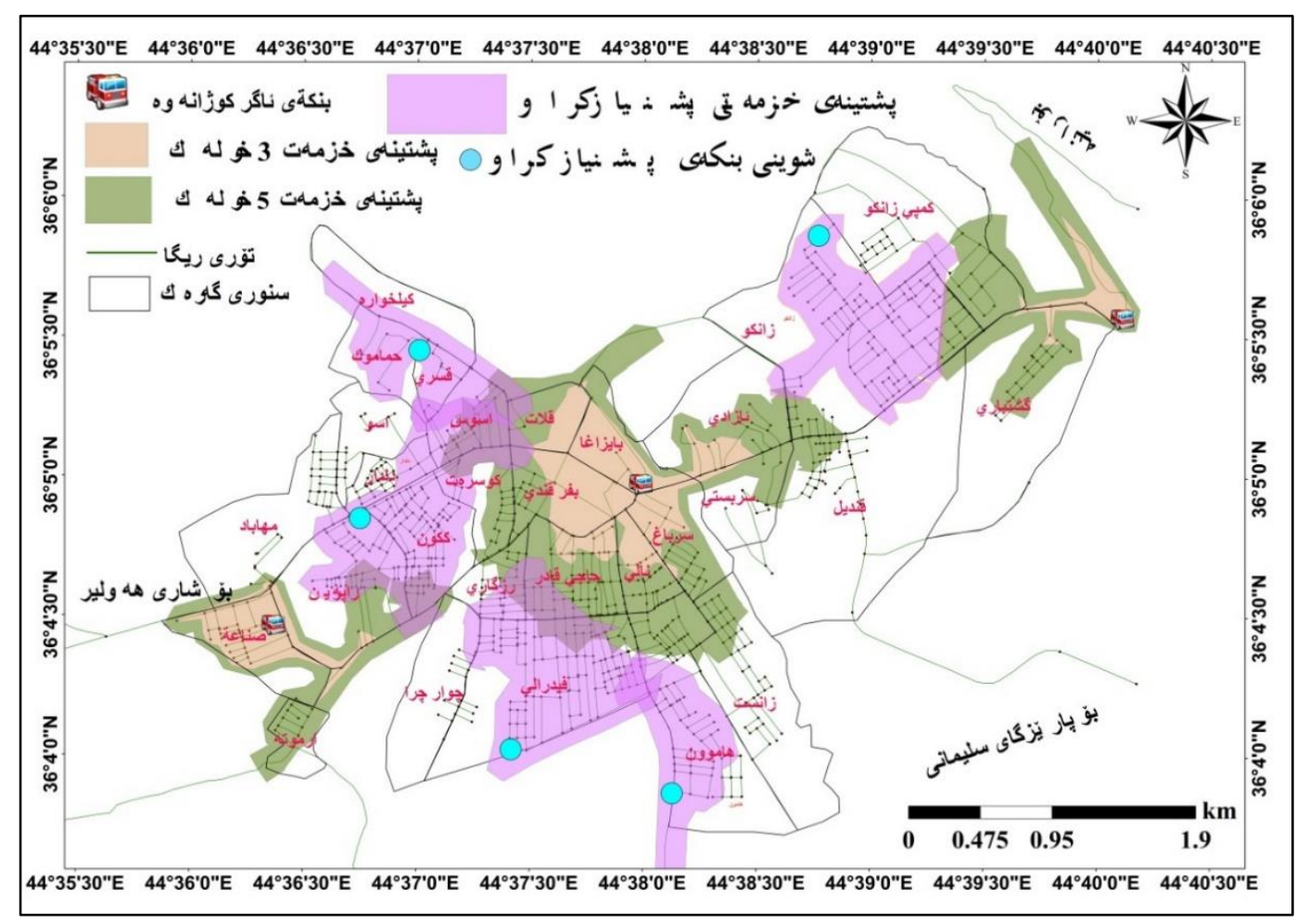

كارى تويزّهر دهرئهنجامى كردارى Network Analysis 


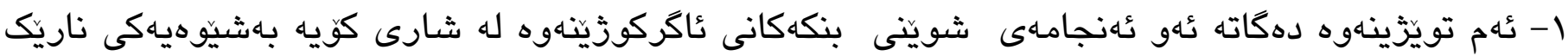
دابهشبوين و زمارهيان كهمه دور له بيّوهره جيهانييهكان و رِهاوى فراونبونى شارهكهيان تيّا نهكراوه،

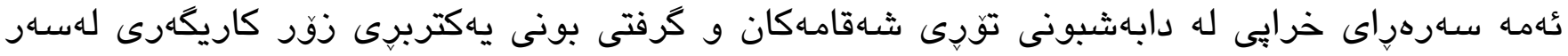

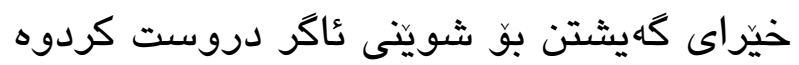

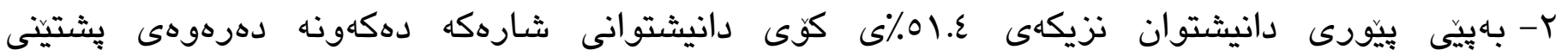
خزمستكوزارى عاكركوزينَهوه.

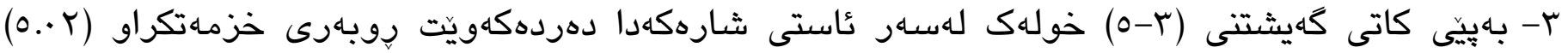

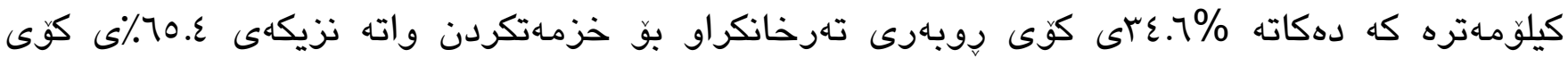

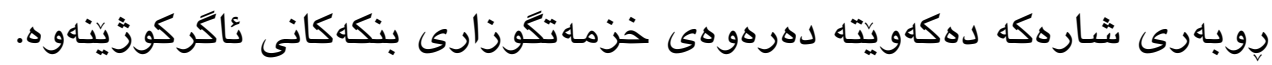

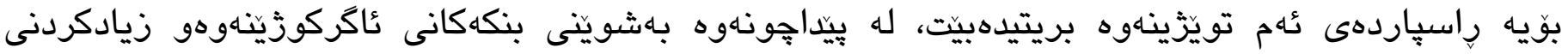

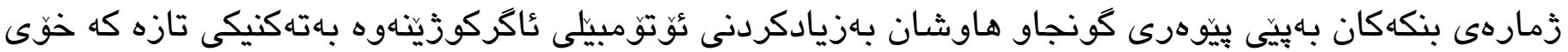
له نهخشهى ديجتالى بيينى بو دياريكردنى رِاستهوخق بوّ شوينّى عاكركهاوتناهوه. 


\title{
Locational Analysis of the Distributions of Fire Extinguisher Stations in Koya With the Use of Geographic Information Systems
}

\section{Rostam Salam Aziz}

Geography Department, Faculty of Education, Koya University, Koya, Kurdistan Region, Iraq. E-mail: rostam.salam@koyauniversity.org

\begin{abstract}
:
The distribution and the competence of firefighting stations in koya town is one of the main problems that this town suffers from, and this led us to conduct an academic study in this respect with the use of Geographic Information Systems. This system illustrates the competence and the services of firefighting stations according to world standard in terms of the times that they take (3-5 minutes) to arrive at the destination according to the distance and the road network, so based on these criteria, the firefighting service can only cover (34\%) of the town. It can be deduced that this problem mainly results from misdistribution of firefighting stations and the poor road transportation network. This study, basing on the universal standards, proposes five new firefighting stations in koya in order to be able to cover the whole town and offer a good service in this respect for the present time and for future.
\end{abstract}

Keywords: Firefighting Stations, Transportation Networks, Network Analysis, GIS. 
Using GIS in Hotspots Analysis and for Forest Fire Risk Zones Mapping in the , . . 11 ‘ F . .C ،Cáceres, Volume 13, Papers in Resource Analysis, Saint Mary's University of .Yeguare Region, Southeastern Honduras .Minnesota University Central Services Press. Winona, MN. Retrieved (date) .,GIS based fire analysis and production of fire-risk maps: The Trabzon experience . +1 • ‘R. 'Nisanci, .Scientific Research and Essays Vol. 5(9), pp. 970-977, 4 May, 2010 .Analysis of Characteristics and Factors Influencing Fire Incidents Response . . 10 ، J. . A ‘Al-Jarallah

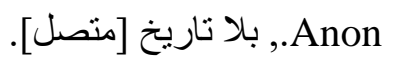
NO 23, International Association of Fire and Rescue Services Center of Fire Statistics . r. 11 ،CTIF معروف: Copyright by Center of Fire Statistics of CTIF 2018

The Impact of Worst Fire Prevention Plan and Disaster Management at . .19 ، S. .a .M ‘Engr. M. U. Shahid Global Environment, Health and Safety, Vol.3 .High Density Urban-Area: A Case Study of Ali Enterprises

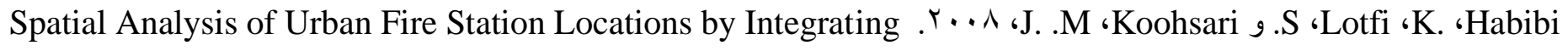
Journal of Applied Sciences . .AHP Model and IO Logic Using GIS (A Case Study of Zone 6 of Tehran) .December 2008 https://reliefweb.int/map/iraq/iraq-erbil-governorate-reference-map- . . . 17 ،W. .K ،Mahmood g.Y .H ‘Haddad ] 2020-5-may-2020

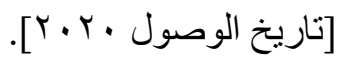
بلا تاريخ [متصل].W .K ،Mahmood و.Y .H ‘Haddad

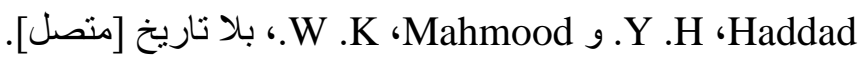

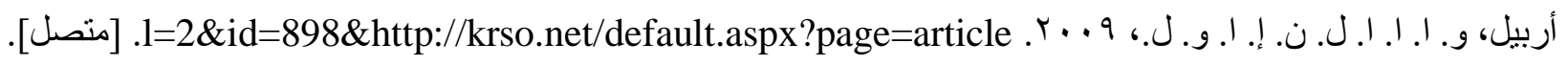


مجيد ، . م.ع. ا. و عطا ، ع. ا. ـ ض.، 19 ـ ب. تقييم كفاءة توزيع مراكز الدفاع المدني في المراكز الحضرية لمحافظة واسط. مجلة واسط، مجلــة كليـة التربيـة، العــدد

$$
\text { السابع والثالثون الجزء الثاني/تشرين الثاني / 19 ـ ب. }
$$

الخاروف, ، ر. . ع.، هزايمة,، خ. و المومني، م.، Y ا •Y. تحليل و اقع خدمات الدفاع المدني في محافظة عجلون ـ الأردن باستخدام نظم

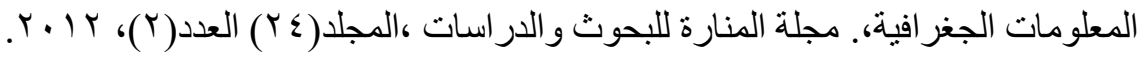

فارس، ا. ع. و ربيع،، م. ص.، ب ا ـ r. التحليل المكاني ل مر اكز ا,طفاء في مدينة بغداد باستخدام نظم المعلومات الجغر افية. مجلة كلية

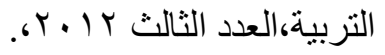
وزارة الاعمار والاسكان-، · · •. كراس معايير الإسكان الحضري.

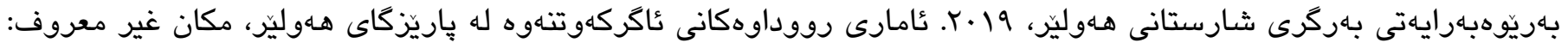
رايّورتى سالآنه.

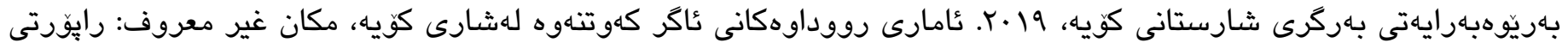
سالانه.

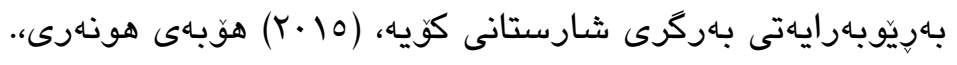
داتا و زانيارى دانيشتوانى كَرهكَكانى شارى كويه (10 (Y) ئفهرمانكهى ثامارى كويه. عمر، ل. و.، 10 · r. بنهماكانى جوكرافياى كَهتوكوزار له قهزاى كويه. كويه: سونتور ليكوليناهوهى يهخشى كويه. 